\title{
EL LENGUAJE POLÍTICO DEL 15-M: HACIA UNA NUEVA RETÓRICA DE LA INDIGNACIÓN
}

\author{
15-M POLITICAL LANGUAGE: TOWARD AN \\ INDIGNADO'S NEW RETHORIC
}

\author{
Nuria PÉREZ VICENTE \\ Università degli Studi di Macerata (Italia) / SELITEN@T \\ nuria.perez@unimc.it
}

Resumen: Este artículo se plantea estudiar la nueva retórica propuesta por una actual protesta ciudadana, la emprendida por los llamados «indignados», el 15 de mayo de 2011, en Madrid. Estudiaremos la que es una de sus principales formas de expresión, es decir, los eslóganes escritos en pancartas y carteles para comprobar que su evidente intención retórica tiene una fuerte finalidad persuasiva pero, sobre todo, constituye una forma de subversión lingüística encaminada a romper los tradicionales esquemas comunicativos.

Abstract: The purpose of this article is to study the new rhetoric proposed by a current citizen protest, which was undertaken by so-called «indignados» on May 15th, 2011, in Madrid. We'll study one of its main forms of expression, the slogans written on banners and posters, to check that their obvious rhetoric intention not only has a strong persuasive purpose: it is, above all, a 
form of linguistic subversion aimed at breaking the traditional communication schemes.

Palabras clave: Lenguaje político. Indignados. 15-M. Retórica. Política.

Key Words: Political language. Indignados. 15-M. Rhetoric. Policy.

En este trabajo se estudia la nueva retórica propuesta por ciertos grupos de acción ciudadana surgidos en los albores del siglo XXI. Para ello nos centraremos en una manifestación muy actual, la protesta emprendida por los llamados «indignados», el 15 de mayo de 2011 en la Puerta del Sol de Madrid. Estudiaremos la que es una de sus principales formas de expresión, es decir, los eslóganes escritos en pancartas y carteles llevados por los propios manifestantes, o distribuidos en el mobiliario urbano. Veremos que su evidente intención retórica, que tanto la acerca al lenguaje figurado por excelencia, el de la literatura, tiene funciones que poco tienen que ver con el simple ornato: la retórica de los «indignados», lejos de ser un juego o una frivolidad, tiene fuerte finalidad persuasiva y, sobre todo, constituye una forma de subversión lingüística encaminada a romper los tradicionales esquemas comunicativos.

El también llamado movimiento 15-M es ante todo una movilización pacífica ciudadana. Forjado al calor de Internet y de las redes sociales, está constituido por gente de todas las edades y condiciones, gente «normal y corriente», como ellos mismos se autodefinen (AA.VV., 2011: 7) ${ }^{1}$, que participan a título individual o como integrantes de diferentes plataformas ciudadanas, foros, $b \log s$ o redes sociales. Independientemente de su filiación política $^{2}$ o religiosa, los une el hecho de «estar preocupados e indignados por el panorama político, económico y social que vemos a nuestro alrededor. Por la corrupción de los políticos, empresarios y banqueros. Por la indefensión del ciudadano de a pie» (AAVV, 2011: 7). Su intención es promover una democracia más participativa y directa, alejada del bipartidismo que en España representan los dos partidos mayoritarios, PP y PSOE, y libre del dominio de bancos y corporaciones financieras.

El movimiento, enmarcado en un primer momento en el centro de Madrid (en la Puerta del Sol), se ha extendido como una mancha de aceite, y

${ }^{1}$ Es el manifiesto del colectivo ciudadano «Democracia Real Ya», uno de los principales integrantes de los «indignados». Se puede encontrar en Internet: http://www.democraciarealya.es.

2 «No somos ni de izquierdas ni de derechas. Somos los de abajo y vamos a por los de arriba». Irene Sánchez en http://politica.elpais.com/politica/2011/10/10/actualidad/1318247674_765656.html. 
hoy en día pueden encontrarse focos de la protesta en al menos cuarenta y cinco países de los cinco continentes. Es fácil ver conexiones entre los «indignados» y movimientos internacionales como los no global. Ambos destacan por su carácter reticular y global (Cosenza, 2007: 39), que confluye en lo que se ha venido en llamar el «mediactivismo» ${ }^{3}$ o activismo en los medios (Pasquinelli, 2002). Éste nace de la convicción de que su supervivencia y posibilidades de acción están directamente relacionadas con su capacidad de comunicación, la cual se produce sobre todo a través de Internet ${ }^{4}$. Esta dependencia de los mass-media constituye la índole de tales plataformas, las cuales, de forma absolutamente consciente, utilizan los mismos instrumentos que aquellos les proporcionan. «Usiamo i linguaggi vincenti» - afirma uno de los activistas - , «quelli che arrivano alle persone [...]. Questa è la società della comunicazione: non possiamo ignorare i codici» (Cosenza, 2007: 46) De esta forma, actuando «desde dentro» del sistema pero alterando los habituales moldes lingüísticos, los «indignados» pretenden, como veremos, «darle la vuelta a la tortilla», crear otra realidad ${ }^{6}$ y demostrar que es posible pensar y actuar de otra manera, alejándose de los esquemas impuestos por nuestra sociedad.

En este trabajo, sin embargo, no vamos a detenernos en los aspectos mass-mediales del movimiento. Queremos centrarnos en cambio en una forma de expresión muy concreta que ha llamado poderosamente la atención a la opinión pública: en primer lugar, por su proliferación y en segundo por su enorme creatividad, nos referimos a los eslóganes que han inundado literalmente manifestaciones y sentadas. Muchos de ellos se han repetido hasta la saciedad («no nos representan», «no hay pan para tanto chorizo»), otros son fruto de la improvisación («yo digo lo ke kiero»), y muchos más res-

3 Término que Pasquinelli (2002) define mediante su acción política (autocontrol de los medios contra el pensamiento único de los monopolios), lúdica (juego con los medios para montarlos y desmontarlos) y creativa (para construir un nuevo imaginario, entendiendo la comunicación como narración colectiva o mitopoiesis).

${ }^{4}$ Muchos critican, sin embargo, el pretendido carácter universal de estos movimientos, ya que la llamada «brecha digital» impide que gran parte de la población mundial tenga acceso a las tecnologías informáticas. Véase Cosenza (2007: 42).

${ }^{5}$ El uso de Internet tiene otras muchas ventajas. En palabras de Pilar Velasco (2011: 28): «A diferencia de un partido, no hacían falta ni locales, ni teléfonos, ni transportes. Ni siquiera material de oficina. Todo es gratis».

6 Aunque esta realidad sea virtual. La web se convierte en un espacio simbólico de apropiación (Barchiesi, 2004: 56-59), un lugar virtual de complicidad abierto a todos. En él se crea la ilusión de realidad, ya que quien entra en tal proceso de comunicación no tiene capacidad para distinguir entre sujetos reales y virtuales. Se sanciona de este modo la victoria de la comunicación que, en la sociedad actual dominada por los medios, llega a ser mucho más eficaz que la victoria real. 
ponden a momentos muy concretos de la movilización, es decir, están fuertemente contextualizados («sabemos el camino de vuelta» fue la pancarta utilizada tras el desalojo de los manifestantes ante la sede de la Junta Electoral). Pero todos ellos han contribuido, en términos de expresión espontánea de los ciudadanos, a definir y delimitar el contenido de la protesta.

Efectivamente, y a diferencia de los tradicionales eslóganes electorales, los lemas de los «indignados» no han sido realizados por especialistas en marketing político, ni se difunden masivamente a través de todos los canales de comunicación, como cualquier campaña electoral, sino que llegan a sus destinatarios a través de la observación directa, en las manifestaciones, o son propuestos de forma indirecta a la audiencia a través de diferentes medios audiovisuales como Internet. Además, su longitud está condicionada por el propio soporte físico a través del que se expresan: pancartas o carteles, de dimensiones reducidas, pegados en árboles, vallas, farolas o puertas ${ }^{7}$. Deben ser, por tanto, necesariamente breves e impactantes - a veces sólo una o dos palabras: «Así no», «Respeto», «Indignaos!»- y regirse por un principio de economía y densidad expresiva (Fernández Gómez, 2005) que favorezca la lectura rápida y la fácil comprensión del mensaje ${ }^{8}$. Todo ello coincide con las tendencias de una posmodernidad que exige cada vez más mensajes cortos y rápidos (pensemos en avisos, titulares, SMS o e-mail), a la vez que se encuadra en una realidad métrica tan aceptada como la del octosílabo, tradicional verso de romances y refranes (González Martín, 1996: 239).

Pero la brevedad y el alto grado de condensación no responden sólo a una cuestión de límites materiales. Es interesante, en este sentido, recordar que la palabra «eslogan», castellanización del vocablo inglés slogan, proviene etimológicamente de dos palabras gaélicas, sluagh y gairm, que en la antigua Escocia denominaban el «grito de guerra de un clan» (Fernández Gómez, 2005: 94). El eslogan moderno, pues, es ese choque o golpe (catchword, en inglés) breve y conciso, de gran carga perlocutiva, dirigido directamente a la atención del receptor para atraerle hacia la promoción de un producto, si hablamos de publicidad, o de una idea, si nos referimos a la política. De ahí la necesidad de usar recursos estilísticos que resulten chocantes,

7 «La necesidad de expresarse inundó los rincones de la Puerta del Sol [...]. Cada pared o cartel publicitario, cada farola, la entrada del metro, los andamios y los escaparates de las tiendas contaban las historias y demandas de esa enorme red que era movimiento sin saberlo. [...] cada pancarta que se colgaba se escribía en compañía y cada lema formaba parte del relato social que se armaba en la calle. Uno siempre parecía desear haber escrito el mensaje del otro» (Velasco, 2011: 18).

8 Tales características, brevedad y concisión, enlazan con las exigencias de la retórica, según la cual las tres virtudes de la narratio son claridad, brevedad y verosimilitud (Pujante, 2003: 102). 
que intensifiquen y realcen el efecto emotivo, despertando así el pathos - por entrar ya en el terreno de la retórica - que todo texto persuasivo debe suscitar. En palabras de González Martín (1996: 241): «la eficacia comunicativa del eslogan se encuentra en una perfecta pertinencia entre su forma y contenido, por esto es por lo que los buenos eslóganes, al igual que los buenos poemas, resultan intraducibles» ${ }^{9}$.

En tal contexto la retórica resulta imprescindible. La disciplina, como sabemos, nace en Grecia el siglo V a. C. asociada a la política y como máxima expresión de la oratoria. Este «arte de persuasión por la palabra» tenía una finalidad pragmática muy concreta: la de convencer al auditorio en las asambleas. Recordemos que todos los ciudadanos participaban por igual en el gobierno de la polis y que los cargos públicos eran designados por sorteo. La retórica, por tanto, es hija de la democracia; aún más, sin ella no tendría razón de ser (Pujante, 2003: 39). Eso sí, hoy en día debemos hablar necesariamente de una retórica actualizada y moderna, una «nueva retórica», como se denomina la disciplina inaugurada en los años sesenta por Perelman, adaptada a los actuales medios de comunicación y orientada no tanto a lo ornamental como a lo instrumental ${ }^{10}$. Porque no cabe duda de que «la comunicación política moderna sigue siendo fundamentalmente retórica, pues busca, al igual que el discurso político tutelado por la Retórica clásica, generar en el oyente efectos cognitivos que le muevan y le persuadan a una acción social favorable al orador» (López Eire y De Santiago Guervós, 2000: 19). Saber de retórica hoy, como afirma Pujante (2003: 24), es no sólo útil, sino tremendamente actual: la usan publicistas, informadores sociales, difusores de ideologías, asesores de imagen, y por supuesto, políticos.

En buena sustancia, los «indignados» han sabido recoger en sus eslóga-

9 Y sigue: «el eslogan es más eficaz por lo que no dice que por lo que dice; su poder de entrañamiento semántico es muy elevado, frecuentemente el destinatario asume lo dicho, diciéndose lo que el eslogan se limitó a sugerirle» (González Martín, 1996: 151).

10 A partir de Perelman (Perelman y Olbrechts-Tyteca, 2001) la retórica no puede considerarse como mero ornato, embellecedor del discurso. Hoy en día no puede estudiarse sin tener en cuenta que el discurso retórico es constructor del significado. «El problema, contenido globalmente en la reinterpretación del sermo ornatus, va más allá de la consideración de un lenguaje especial, distinto, transnacional dialecto potencial del estándar; porque implica la configuración a través del lenguaje de un modo de entender el mundo. Lo que está ante nuestros ojos cobra un sentido a través del discurso que construimos para hablar de ello» (Pujante, 1998: 9). O en palabras de Van Dijk (1999: 340): «La función principal de [las] estrategias retóricas es manejar los procesos de comprensión del receptor e indirectamente, en consecuencia, las estructuras de los modelos mentales». Por ello, cualquier cambio cualitativo en el discurso influye en el conjunto final. El ejemplo típico es la metáfora, elemento ideológico fundamental del discurso que, como tendremos oportunidad de comprobar, define tanto la forma de pensar del orador como las expectativas del destinatario (Pujante, 2003: 195). 
nes el uso más actual de la retórica, pero haciéndolo, paradójicamente, han regresado al estado más puro de la política, aquel que en la Atenas clásica proclamaba que todo hombre es fundamentalmente un ciudadano, implicado como tal en el gobierno de la polis, y puede y debe, por ello, usar el lenguaje como arma de acción social. Los lemas aquí estudiados demuestran no sólo que la retórica es innata ${ }^{11}$ en el ser humano, sino sobre todo que a través de la ella es posible crear un nuevo lenguaje, una nueva forma de expresión alejada de la comunicación política habitual por motivos tanto cuantitativos como cualitativos. Cuantitativos, porque la gran cantidad y variedad de eslóganes producidos tiene poco que ver con las habituales campañas electorales que giran en torno a un número determinado de ellos; cualitativos, porque acumulan efectos retóricos que, dando la vuelta a los modos tradicionales de ver y comunicar la realidad, contribuyen a la creación discursiva de un adversario que poco tiene que ver con el acostumbrado antagonista político.

Pasemos entonces al estudio de nuestro corpus, el cual está formado por 270 eslóganes, extraídos sobre todo de la prensa y de Internet ${ }^{12}$. Todos ellos corresponden a lemas escritos y expuestos en diferentes soportes durante las manifestaciones y sentadas de los «indignados», desde mayo a agosto de 2011. En una concepción abierta de la retórica que considera a ésta como el arte de explotar de forma óptima las capacidades del lenguaje, vamos a estudiar no sólo tropos y figuras, sino también los campos léxicos y los elementos intertextuales utilizados, ya que sólo una visión de conjunto contribuirá a desvelarnos las particularidades de esta nueva forma de usar el lenguaje. Por último, queremos aclarar que este estudio no pretende ser exhaustivo: hemos seleccionado sólo algunos de los efectos retóricos más significativos, ilustrándolos por medio de ejemplos.

11 Autores como Kennedy (1998: 3; en Pujante, 2003: 34) consideran que la retórica es un fenómeno universal: «una forma de energía mental y emocional». Los procedimientos retóricos tienen su base natural en el comportamiento humano, y dependen de reacciones emotivas asentadas en el cerebro cuya fuente (remota) es probablemente el instinto humano de autoconservación.

12 Las principales fuentes para construir el corpus, además de AA. VV. (2011), Álvarez et alii (2011) y Velasco (2011), han sido YouTube y diferentes páginas web, entre las cuales figuran: http://www.libertaddigital.com/, http://tendenciavital.ning.com, http://www.letra.org/, www.miweb.org/miembros/16-tanya, www.ques.es, http://albherto.wordpress.com, www.movimiento15m.org, www.lavozdigital.es. 


\section{CAMPOS LÉXICOS}

El estudio del léxico empleado en este corpus es importante por varios motivos: el primero de ellos es que, si admitimos que el lenguaje es constructor de significado, no habrá forma mejor de conocer a un emisor que determinar, a través del léxico que emplea, cuál es el universo de objetos, ideas y valores con el que éste elabora su propia imagen de la realidad. En el caso que aquí nos ocupa, la mayor parte de los términos utilizados pueden adscribirse a tres campos léxicos muy determinados que nos indican cuáles son sus principales áreas de interés. Estos son fundamentalmente: 1) el de las instituciones políticas y el lenguaje electoral; 2) el de la economía y la banca; 3) el de la actividad laboral.

En cuanto al primero, destacan los sustantivos «político» $(16)^{13}$, «votar» (16), «política» (5), «derecho» (5) y «voto» (3). Pero el término más empleado es «democracia», que con 17 apariciones se convierte en el sustantivo más recurrente de todo el corpus. El dato es revelador, ya que parece coincidir con lo que es la principal exigencia de los indignados ${ }^{14}$, es decir, regenerar, según ellos, una maltrecha democracia a través de nuevas formas de participación ciudadana que conviertan la vida política «en algo más que introducir una papeleta en una urna cada cuatro años» (Álvarez et alii, 2011: 47). En el campo de la economía y la banca sobresalen los sustantivos «banquero», generalmente en plural (11), seguido de «banco»-o «banca»- (8) y «crisis» (7). Diferentes verbos relacionados con transacciones económicas son «comprar» (1), «vender» (3) y sobre todo «pagar» (6). En cuanto al tercer campo (actividad laboral) hay que subrayar los sustantivos «trabajo» - o su sinónimo «empleo» - (6) y «paro» (4); también «pensión» (3), «jubilación» (2), etc.

Hay campos léxicos menos esperados y por tanto especialmente significativos. Entre ellos el relativo a la imposibilidad de expresión, con vocablos como «silencio» (1), «boca» (2) y «callar» (5) (mientras que «escuchar»aparece sólo una vez); el de la familia: «hijos» (4), «abuelo» (3), padres (1), padre (1) y madre (2); o el que gira en torno al conocimiento y la reflexión, con numerosos sustantivos — «cabeza», «mente», «razón», «idea», «sentido co-

13 Para este apartado, indicamos entre paréntesis el número de recurrencias en el corpus.

14 Tal exigencia coincide con la que fuera principal reivindicación de la Transición española en los años setenta, época en que el término se carga de connotaciones positivas. No había sido así anteriormente, por ejemplo durante la dictadura (Núñez Cabezas y Guerrero Salazar, 2002: 40). Véanse también Lázaro Carreter (1995), Fernández García (1993), San Vicente (2001) y Santos López (2009). 
mún»- y verbos — «pensar» (6), «reflexionar» (4), «estudiar», «aprender», «darse cuenta», «educar»o «enseñar»-. Existe también un campo relacionado con la revolución: el propio sustantivo aparece 6 veces, junto con los verbos «luchar» (7), «vencer» (5) o «tomar» - en el sentido de «conquistar»- (3), y los vocablos «barricada», «concentración», «bomba», «arma», «causa», «rebelde», «adelante», etc.

Cabe destacar igualmente una extensa área léxica dedicada al espacio urbano con términos como «calle» (4), «plaza» (5), «barrio» (1) o el mismo «Madrid» (5). El movimiento, de hecho, se desarrolla fundamentalmente en las calles de la ciudad, esas «ágoras improvisadas ${ }^{15}$ donde se comparte desde el respeto cualquier opinión» (Velasco, 2011: 12). Se produce así una reivindicación del espacio local, cercano al ciudadano, en oposición a lo que Marc Augè (1993) llama el «no lugar» o lugar despersonalizado, sin arraigos, escenario principal de la sociedad moderna. Señalemos por último el campo de sustantivos que denotan colectividad, el cual nos da pistas sobre el destinatario del mensaje. Significativamente, «España» se usa sólo una vez. El término, cargado ideológicamente en época franquista y recuperado después por los poderes democráticos (Fernández Lagunilla, 1999b: 24), no parece interesar mucho a los «indignados», los cuales se dirigen a un receptor más amplio, relacionado con el aspecto global del movimiento: «pueblo» (10), «mundo» (6), etc.

Es importante observar que todos los términos reseñados están cargados de fuertes connotaciones positivas o negativas: si los situáramos a lo largo de un hipotético eje semántico, «democracia» se ubicaría en el polo positivo, frente a «políticos», «política» o «banca», que estarían en el negativo. Ésta es una característica intrínseca de todo texto político que, independientemente de su género, es siempre un «discurso polémico» (Fernández Lagunilla, 1999a: 39) que implica la construcción del antagonista, «del otro». En este caso, si cabe, la cosa es aún más evidente, ya que nos encontramos ante una protesta ciudadana en la que la identificación del contrario - y más cuando éste no es un partido o un personaje determinado - debe ser muy clara para el destinatario. Sin embargo, la originalidad de los lemas de los «indignados» está en que, apoyándose en la retórica, tal como veremos, y en el empleo de ciertos tipos de verbos y de negaciones, consiguen desplazar a lo largo del eje de valores a algunos sustantivos, en principio connotados negativamente, como «sistema», «miedo», «mentira»y «violencia», que de esta manera son «redimidos» hacia posiciones positivas. Nos referimos sobre todo a verbos de transformación,

${ }^{15}$ Castoriadis las denomina «ágoras públicas» (Barchiesi, 2004: 29). 
como «cambiar» $(8)^{16} \mathrm{o}$ «transformar» (1); de movimiento, como «ir» (13), «mover» (1) o «caer» (1); o de impulso hacia delante, como «levantar», «reiniciar», «avanzar», «traspasar», «alcanzar». Afirmar las posibilidades de cambio de tales términos negativos e implicarlos en construcciones que dan a entender que otras realidades son posibles, es una forma de concederles una especie de «segunda oportunidad». Veamos algunos ejemplos:

\section{Este sistema lo vamos a cambiar.}

2. Basta de mentiras: únete! ${ }^{17}$.

3. Parados, moveos!

4. El miedo es la única frontera, traspasémosla.

5. ¡Por favor, sonría! Está cayendo un sistema.

6. La no-violencia es la fuerza que transformará el mundo.

7. Sin miedo habrá futuro.

La elección del vocabulario, por otra parte, se demuestra fundamental para captar a un determinado tipo de destinatario con el que se comparte un lenguaje común; porque la única manera de convencer es hablar la misma lengua, de forma que el receptor logre identificarse con el mensaje ${ }^{18}$. El predominio de gente joven provoca el uso de argot juvenil y coloquialismos. Véase en este sentido la preferencia por abreviaturas (10) ${ }^{19}$ y sufijos (13):

8. Sin casa, sin curro, sin pensión, sin miedo.

9. Sin botellón no nos sacan en la televisión.

10. Sin tele, sin cerveza. Toma la plaza con cabeza.

16 Por el contrario, no aparece el sustantivo «cambio», tan representativo de las fuerzas de izquierda en la Transición, y paradójicamente escogido hoy por la derecha como eslogan electoral: «Empieza el cambio» fue el lema del PP para las elecciones de noviembre de 2011, ganadas por Mariano Rajoy. Sobre el campo léxico del «cambio» en política, véase Arregui (2009).

${ }_{17}$ Muchos de estos eslóganes, que transcribimos literalmente, no incluyen - en consonancia con lenguajes tan actuales como los SMS o los e-mail, y coincidiendo con la lengua inglesa - el signo de admiración o de interrogación al inicio del periodo sintáctico.

18 Todo discurso político encierra, en el fondo, un mensaje electoral. De hecho, los «indignados», en un juego de voces polifónico muy propio de la persuasión (Fernández Lagunilla 1999a), se dirigen a menudo al futuro votante («No nos mires, únete») o, en primera persona, se definen a sí mismos como tales («Mandan los mercados y no los he votado»).

${ }^{19}$ A partir de ahora el número entre paréntesis se refiere al del eslogan. 
11. Únete, madero! tú también eres obrero!

12. Menos Madrid-Barça y más peña en la Plaza.

13. Ni pensionazos, ni sueldazos.

Por idénticos motivos, encontramos en los lemas términos atribuibles a la jerga de la informática:

14. No votes, tuitea.

15. Error del sistema: reinicia!

16. Democracia 1.0 obsoleta. Democracia 2.0 instalándose.

Es también frecuente el empleo de términos coloquiales malsonantes $(17,18,19)$; sin embargo son escasos los insultos, que en tiempos de crisis suelen constituir un arma política frecuente (Núñez Cabezas y Guerrero Salazar, 2002: 63). Es curioso que aquí, más que para descalificar al adversario (20), se refieran al propio emisor (17), porque, como veremos, el sistema de descalificación del «otro» se realiza por medios retóricos, a través tanto de tropos como de figuras retóricas propiamente dichas.

17. Nos tomabais por idiotas?

18. Cabréate!

19. Hasta los huevos de que no haya alternativas.

20. Somos anti-idiotas, no anti-políticos.

21. Y a éstos, ¿quién cojones los ha votado?

Por último, resalta el hecho de que no pocos eslóganes de nuestro corpus estén escritos en inglés, lenguaje hoy en día, nos guste o no, del mundo glo$\mathrm{bal}^{20}$. En ellos se realizan los mismos juegos retóricos que en los lemas en castellano $^{21}$.

${ }^{20}$ En el programa «L'infedele» emitido por el canal de televisión italiano «La 7» (14 de octubre de 2011) se le preguntó a un representante de los «indignados» italianos el porqué de los numerosos eslóganes en inglés. Su respuesta fue que «la crisis es global», y que de hecho había otras muchas pancartas escritas en árabe.

${ }^{21}$ Los tres primeros usan referencias intertextuales: el 22 es una frase, modificada, de los humoristas británicos Monthy Python («Nobody expects the Spanish inquisition»); el 23 alude al famoso eslogan turístico de los años setenta («Spain is different»), mientras que el 24 transforma el lema usado en la campaña presidencial de 2008 por Barack Obama, «Yes, we can». El 27 segmenta y altera, con notable efecto connotativo («crazy»), la palabra inglesa «democracy». 
22. Nobody expects the Spanish revolution.

23. Spain is different, not indifferent.

24. Yes we camp!

25. We defend our dreams!

26. People of Europe, rise up!

27. Demo Crazy.

\section{LOS TROPOS}

Seguimos aquí la diferenciación habitual en retórica entre «tropos» y «figuras»: mientras que los primeros implican la modificación de un elemento léxico al que se le asigna un contenido nuevo, y se manifiestan generalmente como una sustitución de términos, las segundas suelen afectar a un grupo de palabras a las cuales aportan una nueva expresividad. Ambos procedimientos tienen lugar en la elocutio, tercera operación retórica que se ocupa de la confección discursiva en cuanto a manifestación textual. Como ya adelantábamos, los tropos van mucho más allá del simple ornato, aportando cambios cualitativos que influyen en el conjunto final.

\subsection{La metáfora}

Es la expresión más característica de la retórica, y el tropo por excelencia. Su función, más allá de facilitar la comprensión de un concepto complejo, procede de un enorme poder connotativo derivado de las asociaciones subjetivas que establece. Una de las teorías actuales más influyentes, la de Lakoff y Johnson (2007), considera que nuestro propio sistema conceptual, según el cual pensamos y actuamos, es de naturaleza metafórica. Pero, además de constituir un elemento ideológico del discurso que define la forma de pensar del orador, la importancia de las metáforas radica en que ayudan a reforzar las valoraciones tanto positivas como negativas en él generadas, contribuyendo así a la descalificación del adversario. En los lemas estudiados hemos encontrado metáforas de connotación positiva, como «pan» (en sentido de «medios de subsistencia»), «sueño»y «mar» (en el de «deseo, ilusión»). Son metáforas clásicas, muy usadas en literatura - quién no recuerda los versos de Jorge Manrique, «nuestras vidas son los ríos que van a dar en el mar, que es el morir»-, de fuerte efecto icónico, que tienen la ventaja de despertar rápidamente clichés mentales que todos poseemos: 
28. Sin Pan no habrá $\mathrm{Paz}^{22}$.

29. Zapatero nos quita el pan; Esperanza Aguirre, el agua ${ }^{23}$.

30. Hay noches que todavía sueño.

31. Nuestros sueños no caben en sus urnas.

32. Dormíamos, despertamos.

33. Inmigrantes, vosotros sois el mar de Madrid ${ }^{24}$.

Entre las metáforas que aportan connotaciones negativas tenemos, en cambio, términos como «ladrón», «robar» $\mathrm{o}$ «tirano»; pero también «esclavo» ${ }^{25}$, «lacayo»y «borrego». Representan, en el primer caso, una fuerte descalificación del «otro» (políticos, banqueros o fuerzas de poder); en el segundo, una crítica a la actitud pasiva de los ciudadanos:

34. No robéis, para eso estamos banqueros y políticos.

35. No nos falta dinero, nos sobran ladrones.

36. Votar es elegir en secreto quién te robará públicamente.

37. Roban los bancos, no los inmigrantes.

38. Zapatero, lacayo de los banqueros.

39. Pueblo manso, buen esclavo.

40. Yo borrego ¿̇y tú? ${ }^{26}$.

\footnotetext{
${ }^{22}$ Nótese la paranomasia - es decir, la coincidencia parcial de dos significantes en el mismo contexto- subrayada por el uso de mayúsculas.

${ }^{23}$ Se hace referencia a la ley de privatización del agua (Canal de Isabel II) defendida por Esperanza Aguirre, presidenta de la Comunidad de Madrid, entonces.

${ }^{24}$ Este lema rechaza un prejuicio común contra los inmigrantes a través de una colocación, el «mar de Madrid». De todos es sabido que en Madrid no hay mar (recordemos la canción de los Refrescos, de 1989, «Vaya, vaya, aquí no hay playa»), por eso ellos, los inmigrantes, son precisamente lo que siempre han añorado los madrileños. Del mismo modo, contribuyendo a la identificación del antagonista a través de una antítesis, un eslogan que veremos más tarde (102) afirma que «el enemigo no viene en patera, viene en limusina».

${ }^{25}$ La siguiente metáfora, encontrada en otro eslogan, pertenece al mismo campo léxico: «Precarios del mundo, no tenéis nada que perder excepto vuestras cadenas».

${ }^{26}$ Nótese la fuerza connotativa de la interrogación retórica. Tal estrategia se usa en numerosos eslóganes. Su fuerza pragmática es grande cuando, como en este caso, supone una apelación directa al destinatario, que queda así implicado en la comunicación (otro ejemplo: «¿Qué les vas a decir a tus hijos cuando te pregunten dónde estabas? ¿viendo la tele?»). En otras ocasiones plantea preguntas sin aparente respuesta: «Si la política es un chiste, ¿por qué no nos hace gracia?», «Pero... ¿por qué?». A este respecto, véanse también en este artículo los eslóganes números 17, 21, 56 y 106.
} 
Encontramos también metáforas que Lakoff y Jonson (2007) definen como ontológicas, es decir, aquéllas que al recoger nuestras experiencias en términos de objetos y sustancias, nos permiten elegir partes de la misma y tratarlas como entidades discretas o uniformes, con el fin de abarcarlas y entenderlas mejor. En ellas se rechaza la masificación del individuo para «construir» un proyecto ajeno a él (41), o se acusa a bancos y fuerzas políticas de agredirlo o despersonalizarlo (42 y 43). Los eslóganes 44 y 45 son de claro eco revolucionario - nótese la dilogía en «masa», apoyada por el verbo «levantar» (ya que en nuestro esquema mental «arriba» es «positivo» y «abajo» negativo) - , mientras que el 46 y el 47 utilizan mecanismos de equivalencia: son metáforas de aposición que enfrentan el término real con el figurado a través del verbo copulativo o de los dos puntos:

41. Me niego a ser otro ladrillo en el muro.

42. Los bancos nos apedrean, las canteras las pone el gobierno.

43. No somos mercancía en manos de políticos y banqueros!!!

44. Mantén la llama de la revolución.

45. Somos la levadura que levantará la masa.

46. Violencia es cobrar 600 euros.

47. Tahrir' [plaza de El Cairo] de Madrid: Puerta del Sol de Madrid.

Por último, tres ejemplos en los que a través de la metáfora se rechaza el bipartidismo: en el 48 a través del uso del verbo «cambiar» que, como decíamos, contribuye a redefinir los valores negativos y transformarlos en positivos; las dos restantes, rimados, a través de la iconicidad política: en el 49, por medio de los sustantivos «capullo» (en referencia a la rosa socialista y a la injuria de tipo sexual) y «gaviota» (símbolo del PP); en el 50, con los colores que representan a los dos partidos mayoritarios («azul y rojo»):

48. Ni cara A ni cara B. Queremos cambiar de disco.

49. Entre capullos y gaviotas, nos han tomado por idiotas!

50. Azul y rojo, merecéis un desalojo. 


\subsection{La dilogía}

La dilogía o ambigüedad - lo que la retórica clásica llama anfibologíaconsiste en el uso de una palabra con varios significados. Muy cercana a la metáfora, su capacidad connotativa es elevada, ya que da lugar a vistosos juegos de palabras e incorpora efectos humorísticos. En nuestro corpus tenemos numerosos ejemplos, varios de los cuales giran alrededor del sustantivo «sol». Astro por excelencia, se presta a numerosas colocaciones que funcionan como metáforas de valoración muy positiva. Estamos ante un caso de asociación contextual, ya que como sabemos la Puerta del Sol («Sol») es el principal punto de reunión y acampada de los «indignados». Son dilogías que acumulan otros efectos retóricos: mientras que el eslogan 52 presenta una antítesis de tipo hiperbólico y el 53 se refiere a la «clave» musical, el 54 y 55 incorporan elementos intertextuales ${ }^{27}$. Notemos por último el metaplasmo ${ }^{28}-0$ alteración de la forma gráfica de la palabra - del 56:

\section{Nosotros al Sol!}

52. Ya tenemos Sol, ahora queremos la luna.

53. La clave está en SOL.

54. La primavera ha llegado a Sol.

55. En vuestro imperio ya se pone el SOL.

56. Sol-uciones.

57. Usar protector: hay Sol para rato.

Hay otras dilogías de fuerte efecto retórico, como la del lema 58. Especialmente efectivo por su brevedad, construye una analogía - señalada por medios gráficos (mayúscula y comillas) - entre el sustantivo y el apellido del banquero, Emilio Botín. Igualmente efectivos son los eslóganes 59 y 60 , en los que el término «chorizo» alude tanto al embutido como al «ladrón de poca monta» (Moliner, 2007). A esto se añade el valor connotativo de «pan» que, como hemos visto, simboliza metafóricamente a los medios de subsistencia. En el 60 se usa una fórmula típica de las rebajas, mientras que el 61

${ }^{27}$ El primero al referirse a una famosa frase publicitaria, «la primavera ha llegado al Corte Inglés»; el segundo es la conocida paremia referida al imperio de Felipe II, del cual se decía que era tan extenso que en él siempre había alguna zona con luz solar.

${ }^{28}$ No es el único ejemplo: precedentemente veíamos «Demo-crazy» (27). 
retoma el campo léxico de la banca («dar crédito») para hacer un guiño al destinatario. Por último el 62, siempre con una nota de humor, utiliza el doble sentido del sustantivo «banco»:

58. Tu «Botín», mi crisis.

59. No hay pan para tanto chorizo.

60. Chorizo Ibérico, liquidación!

61. No doy crédito!

62. Si te fías de los bancos, acabarás durmiendo en uno.

\subsection{La personificación o prosopopeya}

La personificación atribuye a un objeto inanimado rasgos humanos:

63. Democracia, ¿dónde estás? ${ }^{29}$.

64. Me gustas, Democracia, pero estás como ausente ${ }^{30}$.

65. No somos antisistema, el sistema es antinosotros.

66. Obrero, despierta, el paro está en tu puerta.

67. Yo soy tu banco: vota, consume y icalla!

68. Vota a Nadie. Nadie te dará trabajo. Nadie te comprenderá.

Es significativa la aplicación de la figura al sustantivo «democracia» que es, como ya dijimos, el más recurrente del corpus, el cual se revaloriza positivamente al concedérsele capacidad de movimiento y decisión. El 65, uno de los lemas más conocidos de los «indignados», personaliza en cambio el sustantivo «sistema», connotado negativamente. De esta forma, y a través de la doble negación (con el adverbio «no» y el prefijo «anti»), el esquema habitual se invierte: es el «sistema» el que rechaza al individuo, y no viceversa ${ }^{31}$.

29 Algo similar sucede en «Estoy buscando mis derechos ¿Alguien los ha visto?». El término «derechos» se cosifica, con lo que el verbo «perder» pasa del significado propio de la colocación («perder el derecho a») al de «extraviarse». La misma cosificación se observa, para destacar valores negativos, en «Se vende diputado y democracia» y «Políticos y banqueros, carne pa'l puchero».

${ }^{30}$ El lema reinterpreta un poema de Neruda, musicado por Javier Krahe. Hay otra versión en nuestro corpus: «Me gustas cuando votas porque estás como ausente».

31 De hecho, este lema es también un buen ejemplo de retruécano, figura de dicción de la que hablaremos más adelante. Otra versión similar es «No soy antisistema, el sistema es anti-mí». 
Los ejemplos 66 y 67 contribuyen a reforzar los valores negativos «paro» y «banco», mientras que en el último se le atribuyen rasgos humanos al indefinido «nadie» para conseguir un juego de palabras parecido al del famoso chiste de Abbott y Costello («Quien juega en primera base»).

\section{LAS FIGURAS RETÓRICAS}

Como ya explicamos, a diferencia de los tropos, las figuras conciernen a un grupo de palabras y, más que transformarlas, les añaden significado. Aquí vamos a continuar la distinción clásica entre figuras de dicción y de pensamiento. Las de dicción afectan a la expresión lingüística y por tanto tienen una plasticidad fácil de reconocer; las de pensamiento, más que la forma, alteran al sentido de la palabra con fines expresivos e intensificadores $(\mathrm{Pu}-$ jante, 2003).

Dentro de las de dicción, en nuestro corpus prevalecen las que tradicionalmente se han llamado «figuras de repetición». Tal particularidad tiene que ver, por un lado, con la necesidad de construir un mensaje sencillo y repetitivo, fácil de recordar, que pueda ser recitado en una eventual marcha callejera. Por otro, se trata, como ya hemos dicho, de reforzar valores positivos y negativos, y en este sentido la acumulatio (así denominada por la retórica) es muy efectiva. Además, si «la palabra es acción» (Fernández Lagunilla, 1999a: 21), la reiteración sirve sin duda para reforzar tal acto perlocutivo.

\subsection{Figuras de dicción}

\subsubsection{Anáfora}

Es el tipo de repetición más instintiva y por tanto más habitual, es decir, la que se produce al inicio de la estructura sintáctica. Además de constituir fórmulas paralelas, muy efectivas por su brevedad, son una excelente forma de mostrar insistencia (Pujante, 2003):

69. Sin casa, sin curro, sin pensión, sin miedo.

70. Vamos despacio porque vamos lejos.

71. Sin tele, sin cerveza. Toma la plaza con cabeza.

72. Generación NINI: ni nos vamos, ni nos callamos, ni PP ni PSOE. 
73. Que no, que no, que no nos representan.

74. No tenemos nombre, no tenemos líder y tampoco tenemos prisa.

Notemos que en muchas de ellas la anáfora contribuye a reiterar la negación. En el 72 da lugar a un neologismo: «Nini», mientras que en el 73 actúa como refuerzo coloquial, adecuado para ser recitado.

\subsubsection{Homoteleuton o rima}

El homoteleuton se da cuando dos o más palabras tienen terminaciones iguales o parecidas. Encontramos muchos ejemplos, y su función es doble: por una parte contribuyen a que el mensaje sea recibido con más facilidad, y mejor memorizado; por otra, sirven, como veíamos, para que el lema sea recitado en las manifestaciones. Veamos algunos ejemplos:

75. Cuidado, el pueblo está enojado.

76. Político, ladrón, devuelve la comisión.

77. La nación no da ni ayuda ni solución.

78. No tenemos casa, nos quedamos en la plaza.

79. Más educación, menos corrupción.

80. El próximo parado, que sea un diputado.

81. A Rajoy y Zapatero que les voten los banqueros.

Se trata de estructuras muy breves, con un alto grado de paralelismo sintáctico. La rima más usada es la consonante, y especialmente frecuente la terminación en -ón, de efecto contundente. Es interesante comprobar que su uso se corresponde con los eslóganes que implican mayor protesta, y que utilizan por ello un vocabulario más objetivo y menos figurado, proveniente de áreas léxicas relacionadas con el lenguaje electoral y económico.

\subsubsection{Retruécano}

Conocido en la retórica clásica como commutatio (Pujante, 2003: 270), el retruécano es una inversión de vocablos. Consiste en contraponer pensamientos inversos, utilizando los mismos términos, pero repitiéndolos, con 
cambio recíproco de su función sintáctica. Produce un efecto inesperado y se muestra especialmente útil para mostrar la otra cara de la realidad. Es por ello significativo que encontremos un gran número de ellos en el corpus:

82. Ellos nos necesitan. Nosotros a ellos, no!

83. Si los políticos hacen el payaso, los payasos tendremos que hacer política.

84. De la revolución del placer, al placer de la revolución.

85 . Es mejor luchar y perder que perder sin haber luchado.

86. Me sobra mucho mes al final del sueldo.

Observemos que muchos introducen una oposición de sujetos («ellos»/ «nosotros»), contribuyendo así a una mejor delimitación del «otro». El 83 contiene una asociación metafórica ( «político $=$ payaso») ${ }^{32}$. Los dos retruécanos más puros son el 84 y 85: el primero retoma ecos del sesenta y ocho, e incita, como el segundo, a la revolución. Caso especial es el lema 86, juego de palabras construido a partir de una inversión de términos que no se repiten. Se consigue con ello una eficaz ironía que pone al descubierto la realidad de los hechos.

\subsubsection{Derivación}

En este corpus hay otras figuras de repetición más conceptuales, como la derivación, es decir, el empleo de palabras procedentes de un mismo étimo o raíz:

87. Queremos una justicia justa.

88. Acción Reacción.

89. La banca, al banquillo.

El ejemplo 87 es además un pleonasmo o redundancia, ya que no puede (teóricamente) existir una justicia injusta. En el 89 encontramos «banquillo»,

${ }^{32}$ Los «indignados» afirman que después de asistir indefensos a tantos casos de corrupción, «no es extraño que la calle se haya vuelto irreverente», pero se trata de «payasos trágicos, que diría ValleInclán» (Velasco, 2011: 47). 
que es etimológicamente un diminutivo lexicalizado de «banco» (del germano bank) y de su femenino, «banca».

\subsubsection{Antanaclasis}

La antanaclasis, figura cercana a la dilogía, consiste en la repetición de una misma palabra con diferentes sentidos:

90. Los ricos están ricos. Cómetelos!

91. La banca siempre gana y no me da la gana.

92. No les votes: bótales!!

93. Sin vivienda no hay viviendo.

El ejemplo 90 usa dos sentidos diferentes de «rico»: el primero es el sustantivo («persona adinerada»), el segundo el adjetivo («agradable al paladar»). De igual modo, el 91 emplea «ganar» como verbo, y luego formando parte de la colocación coloquial. Especialmente interesante es el 92, que juega con una homofonía entre «botar» («echar a alguien», usado sobre todo en el español de América) y «votar». En el ejemplo 93, en cambio, se podría hablar más específicamente de poliptoton, es decir, de la repetición de una palabra en sus diferentes accidentes gramaticales. En efecto, el lema usa el sustantivo y el gerundio de una misma raíz, lo cual produce un solecismo de mucho impacto («sin vivienda no se puede vivir»).

\subsection{Figuras de Pensamiento}

\subsubsection{Ironía}

Es una figura fundamental, de fuertes implicaciones pragmáticas ${ }^{33}$, ya que «induce una disonancia interpretativa según la cual el hablante dice algo literalmente falso con el objeto de implicar lo opuesto» (Torres Sánchez, 2009: 66). El destinatario tratará de reconstruir la interpretación no literal, re-

${ }^{33}$ Precisamente a la ironía se dedica el estudio de Laura Camargo (Universitat de les Illes Balears) presentado en el último congreso del GRIALE (Grupo de investigación para la pragmática y la ironía del español de la Universidad de Alicante) en diciembre de 2011, titulado «Me sobra mes al final del sueldo: los eslóganes del 15-M y la utilización de la ironía para la expresión del malestar social». 
solviendo la tensión irónica. Su uso en los eslóganes es frecuente, ya que, a través del humor, muestran el otro lado de la realidad:

94. Se alquila esclavo económico.

95. Oferta de empleo: país indignado busca políticos honestos. Entregad currículum en Sol. Abstenerse los actuales.

96. Yo soy tu banco, vota, consuma y calla.

97. Las putas insistimos: los políticos no son nuestros hijos.

98. Si quisiera molestar, ya os habríais dado cuenta.

99. No somos mendigos: practicamos para el futuro.

El efecto irónico se puede conseguir de muchas maneras: lemas como el 94, de naturaleza metafórica, o el 95, lo hacen tomando prestado otro género textual: el de los anuncios por palabras. Pero, sobre todo, es significativo que muchos de ellos adopten, polifónicamente hablando, la voz del «otro», el cual expone su propio punto de vista para que el destinatario capte el verdadero mensaje que hay detrás. De hecho toda ironía - como podemos observar en el lema 96, en el que hay además una personificación - incluye una mención ecoica (Ruiz Gurillo, 2007: 121), es decir, el eco de una opinión que se considera irrelevante o inadecuada. El 97 da voz a un personaje externo, «las putas», para, basándose en una injuria de tipo coloquial («hijo de puta»), descalificar al «otro», en este caso el político. Otros $(98,99)$ utilizan un humor especialmente mordaz, entrando en el terreno del sarcasmo.

\subsubsection{Antítesis}

La antítesis es la contraposición de dos ideas o pensamientos. No se trata de una figura de repetición, pero su mecanismo es similar, al plantear en disposición especular dos elementos opuestos. Son muy numerosos y efectivos, ya que, al destacar dicha oposición, contribuyen poderosamente a la construcción de valores positivos y negativos, enfrentando virtualmente dos sujetos (ellos - nosotros) y reafirmando por tanto la creación del adversario, del «otro». Además, el carácter íntimamente contradictorio (Mortara Garavelli, 2010: 145) de esta figura, favorece la reflexión, y acentúa su poder connotativo: 
100. Ayer estaba indignada, hoy estoy ilusionada.

101. La barricada cierra la calle pero abre el camino.

102. El enemigo no viene en patera, viene en limusina.

103. Nos habéis dejado sin nada, ahora lo queremos todo.

104. No nos falta dinero, nos sobran ladrones.

105. Nos prometen riqueza, nos dan pobreza.

106. Más educación, menos corrupción.

Nos encontramos de nuevo ante estructuras muy simples, repetibles y por tanto fácilmente recordables, apoyadas a veces en la rima. La antítesis o contraposición de vocablos se produce entre adjetivos (100), adverbios (106), indefinidos $(103)$, pero sobre todo verbos $(101,104,105)$ y sustantivos $(102$, $105,106)$. Constituyen por sí mismas un buen ejemplo de paralelismo, repetición parcial o completa de un mismo esquema gramatical; porque si las correspondencias en paralelo son perfectas, como sucede aquí, los contrastes resaltan mucho más.

\subsubsection{La paráfrasis}

Una de las figuras retóricas más usadas en el discurso persuasivo consiste en el aprovechamiento de los conocimientos intertextuales compartidos por parte del emisor y del receptor o, en otras palabras, el uso de «discursos ajenos». Estos textos originales, que aparecen modificados para adaptarse a las nuevas circunstancias y al nuevo mensaje propuesto, son altamente rentables desde un punto de vista retórico, ya que, a través de un juego de ingenio difícil de superar, aportan numerosos elementos connotativos con finalidad irónica, crítica o paradójica. La intertextualidad puede manifestarse a través de la fraseología, es decir, el uso de locuciones, colocaciones o paremias como los siguientes:

107. Calladito estoy más guapo, prefiero ser feo y que me escuchen.

108. No podemos apretarnos el cinturón y bajarnos los pantalones al mismo tiempo.

109. No tenéis ni ideas.

110. No por mucho cotizar te jubilas más temprano. 


\section{Ahora sí que sí: de Madrid al Cielo.}

La intervención sobre locuciones, tan habituales en el registro coloquial y por tanto tan bien conocidas por el destinatario, son un interesante recurso: así, el 107 añade una coda adversativa a «calladito estás más guapo»; el 108 crea un juego de palabras con valor paradójico a partir del término «pantalones» (no podemos ahorrar y humillarnos al mismo tiempo); el 109 origina una dilogía a través del plural («no tener ideas» o creatividad). Igualmente efectivo es el uso de refranes — «no por mucho madrugar amanece más temprano» (110) - o dichos populares, como la conocida frase en alabanza de Madrid $(111)^{34}$.

Observamos también el uso de enunciados fraseológicos: máximas filosóficas — «pienso luego existo», de Descartes (112) - ; fragmentos de poesías — «Juventud, divino tesoro», de Rubén Darío (113), con una significativa pregunta retórica; o «sólo un beso callará mi boca» (114), de Neruda $^{35}-$; conocidas enseñas revolucionarias (115); incluso frases bíblicas (116):

\section{Pienso, luego me indigno ${ }^{36}$.}

113. Juventud, ¿divino tesoro?

114. Sólo un beso callará mi boca.

115. El pueblo, unido, funciona sin partidos ${ }^{37}$.

116. Dejad que los banqueros se acerquen a mí. Espanta banqueros.

En otras ocasiones, la intertextualidad puede adquirir un valor altamente paradójico $^{38}$. Sucede cuando se emplean, alteradas, etiquetas lingüísticas destinadas generalmente a otros fines: «cerrado por defunción» 0 «disculpen las molestias» (117), «manos arriba, esto es un atraco» (119), o «por favor,

${ }^{34}$ La epífora formada a través de la repetición del adverbio «sí» va seguida de la expresión «de Madrid al cielo, y en el cielo, un agujerito para verlo». La frase se hizo popular a finales del siglo XVIII a raíz de las mejoras introducidas por Carlos III que embellecieron la ciudad. Significa que aunque uno muera, necesita el «agujerito» para seguir viendo y disfrutando de la Villa y Corte». En http://madripedia.es/wiki/De_Madrid_al_cielo.

${ }_{35}^{35}$ En el mismo poema se habían basado ya otros lemas (ver nota 29).

${ }^{36}$ Este eslogan presenta variaciones: «Pienso, luego no sirvo», «Pienso, luego estorbo».

${ }^{37}$ Otra versión es «Cabreados, unidos, jamás serán vencidos».

${ }^{38}$ La paradoja, figura de pensamiento cercana a la antítesis, presenta una proposición que conlleva una contradicción lógica o una situación que infringe el sentido común. Aparece en diverso grado en numerosos eslóganes, a veces referida a hechos de actualidad: «Vivo en un país donde puedo acampar para ver a Justin Bieber, pero no para defender mis derechos». 
sonría» (120):

117. Cerrado por revolución. Disfruten las molestias.

118. Estamos cambiando el mundo. Disculpen las molestias.

119. Manos arriba, esto es un contrato.

120. ¡Por favor, sonría! Está cayendo un sistema.

Por último, la intertextualidad se manifiesta a través de títulos de libros y películas, versos, etc.:

121. Rebeldes sin casa ${ }^{39}$.

122. Vota al lado oscuro PP\$OE. Siente el poder de la banca.

123. Un banquero se balanceaba sobre la burbuja inmobiliaria...

124. Bienvenidos a la república independiente de nuestra plaza.

Obsérvese el juego paranomásico entre «casa» y «causa» (121) realizado a partir del título de la conocida película de James Dean (Rebelde sin causa); el 122 , en cambio, altera una frase proveniente de La guerra de las galaxias; igualmente productivas resultan las letras de canciones -el 123 usa un conocido estribillo infantil («un elefante se balanceaba sobre la tela de una araña») - o los anuncios publicitarios -el 124 retoma una publicidad de Ikea-.

\section{CONCLUSIONES}

Lo anteriormente expuesto nos lleva a afirmar que los lemas de los «indignados» responden adecuadamente a sus intenciones. En primer lugar, porque tropos y figuras, más allá de ser un simple ornato, aportan cambios cualitativos que despiertan el pathos que todo texto persuasivo debe suscitar. En segundo lugar, porque gracias a una eficaz selección léxica y a un esmerado uso de la retórica consiguen, como decíamos, «darle la vuelta a la tortilla», ofreciendo otras posibilidades que se ocultan detrás de los esquemas habituales de pensamiento. Esto se logra a través de tropos como la metáfora, la dilogía y la personificación, que sustituyen unos términos por otros, sugiriendo otra lectura de la realidad, y de figuras retóricas entre las que des-

${ }^{39}$ Hay otra versión de este eslogan, con un retruécano: «Ya no hay rebeldes sin causa, hay causas para rebelarse. Seamos realistas: pidamos lo imposible». 
tacan el retruécano, la antítesis y la ironía, que invierten o contraponen situaciones para mostrarnos nuevas perspectivas. También la paráfrasis, es decir, la alteración o manipulación del universo intertextual compartido por emisor y receptor, sirve a los mismos fines. Tal acto perlocutivo, constituido por la propia intencionalidad del texto, se refuerza e intensifica con el uso de figuras de repetición como la anáfora o la rima, las cuales sirven a su vez a un motivo contextual, el de la propia manifestación callejera que necesita repetir los lemas para que estos sean recitados y recordados.

Es decir, los eslóganes de los «indignados», aún compartiendo muchas de las características de cualquier texto político, acumulan efectos retóricos encaminados a unos fines muy determinados. De hecho, se observa la ausencia de ciertos recursos muy usados en política, que en este género textual no tendrían ningún sentido: el eufemismo o la atenuación, que esconderían hechos que ellos, por el contrario, quieren poner de manifiesto; o el circunloquio, mecanismo explicativo que alejaría el discurso del tema central de la protesta. Todo ello sin olvidar que el destinatario forma pragmáticamente parte del acto comunicativo, motivo por el cual es importante que el mensaje le venga comunicado de forma atrayente y seductora, con un lenguaje plástico, un tono lúdico, y fuertes notas de humor e ironía. Y para estos fines, el «arma» clásica de la retórica, se sigue demostrando especialmente eficaz.

Por todo ello, es importante fabricar imaginarios positivos y crear, en suma, una forma alternativa de comunicación. Porque si la realidad se construye a través del lenguaje (Álvarez et alii, 2011: 16), darle la vuelta puede convertirse en una acción verdaderamente revolucionaria. Los «indignados», en síntesis, tratan con sus lemas de crear un vocabulario nuevo, «resignificando» palabras que ya existían, como «democracia»; rellenando viejas etiquetas con otros contenidos, como en «no somos antisistema, el sistema es antinosotros», «Me sobra mucho mes al final del sueldo»o «Pienso, luego me indigno»; usando de forma diferente locuciones y frases populares, metáforas y dilogías; o empleando la ironía, y en general de todo el sistema retórico. Se hace necesario crear un nuevo lenguaje que abra las puertas a nuevas formas de razonar. Esperemos que con el tiempo se haga realidad lo expresado en uno de los eslóganes de nuestro corpus, y que «otra manera de pensar sea posible».

\section{REFERENCIAS BIBLIOGRÁFICAS}

AA. VV. (2011). ¡Indignados! 15-M. Madrid: Mandala Ediciones. 
ÁlVAREZ, K.; GALLEGO, P.; GÁNDARA, F. y RIVAS, O. (2011). Nosotros, los indignados. Barcelona: Destino.

ARREGUI, J. A. (2009). Por el cambio. 30 años de propaganda política en España. Sevilla: Comunicación Social.

AUGÈ, M. (1993). Los no lugares: espacios del anonimato. Barcelon: Gedisa [original: Non-lieux, introduction à une anthropologie de la surmodernité (1992). Paris: Seuil].

BARCHIESI, A. (2004). Chiapas-Seattle-Genova. Tattiche comunicative nei discorsi e nelle manifestazioni antiglobalizzazione. Tesis doctoral, Università degli Studi di Macerata (que puede leerse en http://lgxserve.ciseca.uniba.it/lei/tfo/public/4/mariaamaliabarchiesi197_4.pdf).

COSENZA, G. (2007). «Movimenti, reti, partecipazione: un'altra comunicazione è possibile?». En Semiotica della comunicazione politica, G. Cosenza (ed.), 37-71. Roma: Carocci.

FERNÁNDEZ GARCÍA, M. J. (1993). Parlamento y lenguaje: el lenguaje político en la Asamblea de Extremadura, 1983-1987. Mérida: Departamento de Publicaciones de la Asamblea de Extremadura.

FERNÁNDEZ GÓMEZ, J. D. (2005). «Eslóganes, jingles y otras frases felices». En Lenguaje publicitario, M. ${ }^{a}$ Victoria Romero (ed.), 89-112. Barcelona: Ariel.

FERNÁNDEZ LAGUNILLA, M. (1999a). La lengua en la comunicación política I: el discurso del poder. Madrid: Arco / Libros.

- (1999b). La lengua en la comunicación política II: la palabra del poder. Madrid: Arco / Libros.

GONZÁLEZ MARTÍN, J. (1996). Teoría general de la publicidad. Madrid: Fondo de Cultura Económica.

KENNEDY, G. A. (1998). Comparative Retoric. An Historical and CrossCultural Introduction. Nueva York-Oxford: Oxford University Press.

LAKOFF, G. y JOHNSON, M. (2007). Metáforas de la vida cotidiana. Madrid: Cátedra.

LÁZARO CARRETER, F. (1995). «Viejo lenguaje, ¿nuevas ideas?». En Política, lengua y nación, M. Alvar (ed.), 33-48. Madrid: Fundación Friedrich Ebert.

LÓPEZ EIRE, A. y DE SANTIAGO GUERVOS, J. (2000). Retórica y comunicación política. Madrid: Cátedra. 
MOLINER, María (2007). Diccionario de uso del español. Madrid: Gredos.

MORTARA GARAVELLI, B. (2010). Il parlar figurato. Manualetto di figure retoriche. Bari: Laterza.

NÚÑEZ CABEZAS, E. A. y GUERRERO SALAZAR, S. (2002). El lenguaje político español. Madrid: Cátedra.

PASQUINELLI, M. (ed.) (2002). Media Activism. Strategie e pratiche della comunicazione indipendente. Roma: DeriveApprodi.

PERELMAN, C. y OLBRECHTS-TYTECA, L. (2001). Trattato dell'argomentazione. Milano: Einaudi [original: Traité de l'argumentation: La nouvelle rhétorique. Parigi: Presses Universitaires de France (1958)].

PUJANTE, D. (1998). «El discurso político como discurso retórico. Estado de la cuestión». En http://www.marisolcollazos.es/discurso/Discursopolitico-Pujante.pdf.

- (2003). Manual de Retórica. Madrid: Castalia.

RUIZ GURILLO, L. (2007). Hechos pragmáticos del español. Alicante: Publicaciones de la Universidad.

SAN VICENTE, F. (2001). La lengua de los nuevos españoles. Zaragoza: Pórtico.

SANTOS LÓPEZ, J. (2009). «El lenguaje político». En Las lenguas de especialidad en español, Calvi, Bordonaba y Mapelli (eds.). Roma: Carocci.

TORRES SÁNCHEZ, M. Á. (2009). «La relevancia». En Dime con quien ironizas y te diré quién eres. Una aproximación pragmática a la ironía, L. Ruiz Gurillo y X. A. Padilla (eds.), 65-87. Frankfurt am Main: Peter Lang.

VAN DIJK, Th. (1999). Ideología. Una aproximación multidisciplinaria. Barcelona: Gedisa.

VELASCO, P. (2011). No nos representan. El manifiesto de los indignados en 25 propuestas. Barcelona: Planeta.

Recibido el 22 de enero de 2012.

Aceptado el 30 de septiembre de 2012. 